\title{
INVESTIGATING THE ANTECEDENTS OF CONSUMER BRAND ENGAGEMENT TO LUXURY BRANDS ON SOCIAL MEDIA
}

\author{
Angga Febrian ${ }^{* 1}$, Larasati Ahluwalia* \\ ${ }^{*}$ Universitas Teknokrat Indonesia \\ Jl. Zainal Abidin Pagaralam, No.9-11, Labuhan Ratu, Kota Bandar Lampung 35132, Indonesia
}

\begin{abstract}
The purpose of this study is to analyze the antecedent consumer involvement and brand self expressiveness and brand community identification of the three dimensions of consumer brand engagement (CBE) (cognitive, emotional, behavior) in the luxury brand on social media. The data was collected through an online questionnaire which was filled in by 125 respondents who have experience in buying luxury brands using purposive sampling. The empirical study was conducted using structural equation modeling SmartPls. The results of the study stated that Consumer Involvement has a negative impact, brand self expressiveness and consumer brand identification have a positive impact on dimensions of CBE. Tests were also conducted to see the consequences of CBE, namely an increase in brand image and brand loyalty. Managers of luxury brand companies must increase CBE by utilizing and managing consumers following social media and creating communities to make it easier for consumers to get to know the advantages of luxury brand products. This study is a pioneer, as it extends the consumer engagement model to the social media context luxury brand by adding brand community identification as an antecedent CBE.
\end{abstract}

Keywords: consumer brand engagement, brand image, brand loyalty, luxury brand, social media

\begin{abstract}
Abstrak: Tujuan dari penelitian ini adalah untuk menganalisis anteseden dari keterlibatan konsumen, ekspresi diri merek dan identifikasi komunitas merek dari tiga dimensi consumer brand engagement (CBE) (kognitif, emosional, perilaku) pada merek mewah di media sosial. Pengumpulan data dilakukan melalui kuesioner online yang diisi oleh 125 responden yang memiliki pengalaman membeli merek mewah dengan cara purposive sampling. Pendekatan dengan menggunakan structural equation modelling SmartPls. Hasil penelitian menyatakan bahwa keterlibatan konsumen memiliki dampak negatif, ekspresi diri merek dan identifikasi merek konsumen berdampak positif pada dimensi CBE. Pengujian juga dilakukan untuk melihat konsekuensi dari CBE yaitu peningkatan citra merek dan loyalitas merek. Manajer perusahaan merek mewah harus meningkatkan CBE dengan memanfaatkan dan mengelola konsumen yang mengikuti media sosial dan menciptakan komunitas agar konsumen lebih mudah mengetahui keunggulan produk merek mewah. Studi ini memperluas model keterlibatan konsumen ke konteks media sosial merek mewah dengan menambahkan identifikasi komunitas merek sebagai anteseden CBE.
\end{abstract}

Kata kunci: keterlibatan merek konsumen, citra merek, loyalitas merek, merek mewah, media sosial

\footnotetext{
${ }^{1}$ Corresponding author:

Email: angga_febrian@teknokrat.ac.id
} 


\section{INTRODUCTION}

The increasing needs of society in interpersonal activities in cyberspace can be shown by the factors that increase the mass used by all people who share information and social relations (Brandão, Pinho, and Rodrigues 2019; Chen and Lin 2019; Appel et al. 2020). Social media changes the way communicate, collaborate, create and create marketing methods that are ultimately used by companies in online marketing activities (Aral, Dellarocas, and Godes 2013; Lina and Permatasari 2020) and maintain customer relationships (Firmiyanti, Satria and Saptono, 2019). Several social networking platforms are well known by companies in helping to do online marketing such as Facebook and Instagram (Fink et al., 2018; Teo, Leng and Phua, 2018). In particular, the millennial generation dominates in accessing social media compared to the generation above and they more often make purchases online from their cellphones (Nielsen Research, 2019).

One of the companies that create millennials as a special target is luxury brand companies because of their habit of enjoying sharing their shopping experiences or relationships with luxury brands (Batat 2019). Luxury brands expand their presence online through social media (Chu, Kamal, and Kim 2019; Martín-Consuegra et al. 2019). Consumers perceive luxury brands as goods that are superior, rare, authentic, and of higher quality than other brands (Chandon, Laurent, and Valette-Florence 2016).

However, the existence of social media causes luxury brands to have no control over the content provided (Britten 2013) and studies conducted in China of luxury brands that have implemented marketing communication strategies on social media are considered ineffective (Chen and Wang 2017). Several challenges must be faced by luxury brands, namely how to present themselves on social media and there are still many luxury brand companies that do not understand communication on social media (Chen and Wang 2017). In other studies, it is stated that luxury brand companies have started to utilize social media and engage and influence customers so that brands can interact directly with customers (Dauriz, Remy, and Sandri 2013). When luxury brand companies can engage customers on social media, it can be used to formulate an effective marketing strategy (Liu, Shin, and Burns 2019). Special knowledge is needed what are the antecedents of consumer brand engagement on social media.

Consumer brand engagement (CBE) is a research topic that is always associated with marketing effectiveness on social media (Oliveira and Fernandes 2020; Febrian and Fadly 2021). CBE is fundamental in the decision-making process for consumers and brand equity (Bowden 2009). It can be said to be a priority for marketers in brand marketing strategy (Hollebeek 2011). CBE is a psychological process in which consumers become increasingly loyal to a brand. This process includes various stages of consumer-brand relationships characterized by increasing levels of commitment and trust, which will result in repeat buying behaviour and long-lasting loyalty (Bowden 2009). On the practitioner side, $\mathrm{CBE}$ is considered as an effort to build strong bonds between brands and consumers through interaction, shared values, experiential content, and rewards (Schultz 2007).

Customer involvement is a measure of success for online marketing through social media (Liu, Shin, and Burns 2019; Febrian et al. 2021). Although there have been previous studies discussing $\mathrm{CBE}$ antecedents with luxury brands (Algharabat et al. 2020; Giakoumaki and Krepapa 2020; Oliveira and Fernandes 2020), namely consumer involvement and brand expressiveness, but have not seen brand community identification factors as $\mathrm{CBE}$ antecedents in brands luxury. Considering that customers in luxury brands need a community to express themselves in social practices in society through various media (Hollebeek, Juric, and Tang 2017). Therefore this study complements previous research (Oliveira and Fernandes 2020) by looking at the influence of brand community identification as an antecedent of CBE on luxury brands on social media.

This study contributes to academics and practitioners in understanding the antecedentrelationships that influence CBE by adding brand community identification that complements previous research models (Hollebeek, Glynn, and Brodie 2014; Oliveira and Fernandes 2020) that can be applied to luxury brands on social media. Furthermore, the research findings will help managers of luxury brand companies to make informed decisions about customer engagement to maximize social media use in influencing brand image and brand loyalty. 


\section{METHODS}

The research was conducted through an online survey to test hypotheses and assess the research model empirically. The sampling technique used is non-probability sampling using purposive sampling so that the researcher only looks at respondents in Indonesia who have experience in shopping for luxury brands who are followed through social media such as Instagram, Facebook, Youtube. As the population cannot be obtained, then the best option for the unknown population is the PLS, and the minimum number of samples used correctly is $>100$ (Rigdon 2016; Sarstedt et al. 2016). The researcher took 125 samples of data from respondents who had criteria by the research needs, which was then carried out by distributing questionnaires with the help of google form. Research data were collected from 2020 to 2021 .

We adopted the previous research questionnaire (Kaur et al. 2019; Oliveira and Fernandes 2020) and adjusted it to apply to the empirical conditions of research in Indonesia. We used a 5-point Likert scale from strongly disagree to strongly agree. Furthermore, model testing uses partial least square which is a variant-based structural equation modelling and uses the SmartPls 3.0. There are two stages in the testing model. The first is testing the measurement model or what is known as the outer model. Table 1 explains that all the question items that make up the variables have a good one by the minimum requirements set $>0.7$ (John 1999). Then the question item can be tested for validity and reliability.

Table 1. Measurement scales

Variable

Outer Loading

Consumer Involvement

I consider [brand] to be a relevant part of my life

0.701

[Brand] is significant to me

0.934

[Brand] means a lot to me

0.910

Brand Self-Expressiveness

[Brand] symbolizes the kind of person I really am

[Brand] reflects my personality

0.885

[Brand] mirrors the real me

0.852

[Brand] contributes to my image

0.816

[Brand] adds to the social 'role' I play

0.724

[Brand] has a positive impact on what others think of me

0.828

[Brand] improves the way society views me

0.748

\section{Brand Community Identification}

[brand] successes are my successes.

When someone praises [brand], it feels like a personal compliment to me

When someone criticizes [brand], it feels like a personal insult to me.

When I talk about [brand], I usually say "we" rather than "they".

I am very interested in what others think about [brand].

I have strong feelings for [brand].

Consumer brand engagement- Cognitive CBE

Interacting with [brand] on social media makes me think about the brand itself 0.866

I think about [brand] a lot when I'm interacting with it on social media 0.895

$\begin{array}{ll}\text { Interacting with [brand] on social media stimulates my interest to learn more about it } & 0.891\end{array}$

Affective CBE

$\begin{array}{lr}\text { I feel very positive when I interact with [brand] on social media } & 0.722\end{array}$

$\begin{array}{ll}\text { Interacting with [brand] on social media makes me happy } & 0.868\end{array}$

$\begin{array}{ll}\text { I feel good when I interact with [brand] on social media } & 0.807\end{array}$

Behavioural CBE

I spend a lot of time checking [brand] on social media compared to other luxury brands 0.817

When I follow luxury brands on social media, I usually interact with [brand] 0.758

[Brand] is one of the luxury brands I usually interact with when using social media 
Table 1. Measurement scales (continue)

\begin{tabular}{lc}
\hline Brand Image & Outer Loading \\
\hline [Brand] has a reputation for quality & 0.826 \\
[Brand] is sophisticated & 0.877 \\
[Brand] is prestigious & 0.901 \\
Brand Loyalty & \\
I say positive things about [brand] to other people & 0.797 \\
I would recommend [brand] to my friends & 0.852 \\
I consider myself to be loyal to [brand] & 0.896 \\
I am dedicated to [brand] & 0.881 \\
[Brand] would be my first choice within luxury brands & 0.819 \\
\hline
\end{tabular}

Table 2 . Construct reliability and validity

\begin{tabular}{lcccc}
\hline & Cronbach's Alpha & $\begin{array}{c}\text { Average Variance } \\
\text { Extracted (AVE) }\end{array}$ & $\begin{array}{c}\text { Composite } \\
\text { Reliability }\end{array}$ & Findings \\
\hline Consumer Involvement & 0.813 & 0.730 & 0.889 & Supported \\
Brand Self Expressiveness & 0.913 & 0.660 & 0.931 & Supported \\
Brand Community Identification & 0.896 & 0.656 & 0.919 & Supported \\
Brand Image & 0.839 & 0.754 & 0.902 & Supported \\
Brand Loyalty & 0.904 & 0.722 & 0.928 & Supported \\
Consumer Brand Engagement & 0.943 & 0.689 & 0.952 & Supported \\
\hline
\end{tabular}

To establish reliability, we used Cronbach's alpha and composite reliability values were used to evaluate a series of variables to be consistent with what was measured. Composite reliability is also used to see the internal consistency of the instruments used. Fornell and Larcker (1981) suggest that the value should be greater than 0.7 . The results obtained can be seen in Table 2, all items of composite reliability instruments show a value of more than 0.7 . This explains that the instrument used is correct in measuring the proposed concept. Furthermore, the use of AVE to determine convergent validity that gets a value above 0.5 is by the required value (Hair et al. 2014).

Testing the measurement model is carried out on each of the constructs that make up the research model in the context of luxury brands. In general, luxury brands are defined as brands that offer premium products, provide pleasure as the main benefit, and connect with consumers emotionally (Hagtvedt and Patrick, 2009). Researchers can see the characteristics of luxury brands through striking perceptions, perceptions of quality, perceptions of hedonism, perceptions of uniqueness, and expanded self-perceptions (Vigneron and Johnson, 2004). Marketers can use social media to communicate luxury brands because it is proven to be effective in influencing customers to engage in brands (Kim and Ko, 2010; Phan et al. 2011). Social media is also able to provide new ways for luxury brands to interact with customers (Chu et al. 2019) and can reach consumers in social communities by building good relationships (Kelly et al. 2010). Especially luxury brands play a key role in the success of brand building (Phan et al. 2011).

Consumer Involvement is a perception generated from customers who have object relevance based on their needs, values, and interests (Zaichkowsky, 1985). Involvement is considered as customer motivation which has consequences on consumer purchases and different communication behaviours (Laurent and Kapferer, 1985). In the online context, involvement can be seen from the direct interaction of customers with the media which can provide benefits to companies in marketing their products which have implications for the formation of customer-brand relationships (Teresa et al. 2014; Oh et al. 2015; Scheinbaum, 2016). Retail companies need to consider consumer involvement because it can be used as an antecedent of consumer brand engagement (Leckie et al. 2016). 
However, it is not only measured by how much customers engage with the brand to see how it affects $\mathrm{CBE}$, marketers can also see the brand expressiveness. Brand expressiveness is assumed to be an impact resulting from a brand that can improve a person's social self-image (Matzler et al. 2011). One of the things that supports this increase is with products that can help someone express themselves (Rozzenkrants et al. 2017). In the context of social media, selfexpressiveness is defined as the willingness of customers to share messages about something that is considered to have more value to be shared with others (Alvarez and Fournier 2016). Another thing can be exemplified in a luxury brand that customers perceive as something that has provided more benefits so that it will influence them to engage in consumer-brand relationships (Atwal and Williams, 2017; Fernandes and Moreira, 2019). For example, when someone wants to join the Apple brand community that some people consider it a luxury, not only because they want to use a high-quality product, but also can raise one's self-image in a community or group (Fazli-Salehi et al. 2020). Previous research has called it brand community identification (Coelho et al. 2018; Kaur et al. 2019; Qiao et al. 2019).

The psychological bond between groups and users is called identification (Cole and Bruch, 2006). Individuals can identify their group with external group prejudice, internal group preference, and classification, as suggested by the social identity theory (Tajfel, 1982). Individuals can passively and actively classify themselves and others into different groups which in turn can influence individual behaviour due to external stimuli (Algesheimer et al. 2005). In practice, the offline environment does not have a strong relationship compared to the online environment because the online environment can reach everyone (Stokburger-Sauer et al. 2012).

Identification can be applied to brand community identification (BCI) online on social media (Qiao et al. 2019). Kim and Park (2001) defined BCI as a brand level that can enhance and express customer identity. however, customer identity can be understood from two perspectives, namely personal identification and the brand's social identification function. The ability of consumers to identify a particular brand with a feeling of affinity for the brand is called personal identification. Meanwhile, when consumers can integrate with groups that make up their social environment it is called brand social identification (Del Río et al. 2001). BCI is effective in influencing CBE in the online environment (Kaur et al. 2019; Qiao et al. 2019). So the researchers proposed these hypotheses:

H1: Consumer involvement has a significant effect on increasing consumer brand engagement

$\mathrm{H} 2$ : Brand self engagement has a significant effect on increasing consumer brand engagement

H3: Brand community identification has a significant effect on increasing consumer brand engagement

Discussions about engagement can be learned from various disciplines and in the marketing science literature. It has been discussed with different objects that are proven to be used in improving performance on social media (Harrigan et al. 2017; Gómez et al. 2019; Machado et al. 2019; Shanahan et al. 2019). Hollebeek, Glynn, and Brodie (2014) offered the concept of CBE which is defined as an individual's level of motivation related to cognitive, emotional, and behavioural activities at the time of the interaction. This research focuses on CBE which has an important role in brand management (Hollebeek et al. 2014; Oliveira and Fernandes, 2020) because it can increase brand image and create customer loyalty to the brand (de Villiers 2015; Chahal and Rani, 2017; Islam et al. 2017; Helme-Guizon and Magnoni, 2019; Oliveira and Fernandes, 2020). Brand image is defined as the beliefs, associations, attitudes, and impressions that customers have (Foroudi et al. 2018). Meanwhile, brand loyalty is defined as a response from consumers to buy back a brand because of good perception of the brand (Oliver 1999; Chaudhuri and Holbrook, 2001). In measuring CBE which can affect brand image and brand loyalty, (Hollebeek et al. 2014) uses three measurement dimensions, namely affection, cognitive processing, and activation (behavioural).

High consumer loyalty can occur when the attitude towards brands in CBE is positive (Hollebeek 2011; Vivek et al. 2012) and there is interaction from brand to consumer outside of purchase (Brodie et al. 2011). CBE has an interactive and immersive nature that leads to a relationship with a brand and a link to customers who have a positive impact (Dwivedi, 2015). This study also sees that there is a relationship between the presence of social media on the brand image when used in luxury brands because it will still help maintain a sense of exclusivity without reducing the brand image (Athwal et al. 2018). Social media marketing on luxury brands is considered effective (Godey et al. 2016), different opinions state that luxury brands have a high exclusive 
image that will threaten accessibility on social media (Park, Im, and Kim 2018). Thus it is stated that:

H4: CBE has a significant effect on brand image

H5: CBE has a significant effect on brand loyalty

As shown in Figure 1 describes a research model that looks at the factors that shape consumer brand engagement which has implications for improving brand image and brand loyalty. So that marketers are required to know these factors to reach a wider range of consumers. After the measurement model is met with validity and reliability. Then performed by testing the structural model or what is known as the inner model. researchers tested the model by doing bootstrapping.

\section{RESULTS}

Emerging literature emphasizes the key role of CBE in consumer-brand relationships. This relationship is done by utilizing social media which is currently a trend in society. So that many companies, especially luxury brand companies, are challenged to reach their customers using social media. Based on the results of interviews conducted, almost all luxury brand customers follow the social media accounts of luxury brand companies to see what products are offered, like Instagram, Facebook, and Youtube social media. Customers also want to get information from these companies. When the information offered is in the form of photos, blogs, or videos on social media, it will influence customers to engage in activities carried out by companies on social media (Bu et al. 2020).

However, the first finding, consumer involvement does not affect CBE. Hypothesis testing is shown in
Table 3 which displays the results with varying values. Hypothesis 1 (H1) has a p-value of $0.60>0.05$ which indicates a positive and insignificant result. Consumer involvement has no significant effect on consumer brand engagement. This involvement is related to the level of consumer interest he gives to brands when accessing social media. These results are inconsistent with previous studies which state that consumer involvement is very important for the antecedents of CBE (Brandão et al. 2019; Oliveira and Fernandes, 2020). This difference occurs because not all consumers think that luxury goods are an important part of life. Luxury goods are only used as complimentary items and are not the main items that must be owned.

Although only as a compliment, when they have the product, they will make them proud to have it. Proven results state that brand expressiveness affects CBE. Hypothesis $2(\mathrm{H} 2)$ has a p-value of 0.000 which shows a positive and significant result. Brand self expressiveness has a significant effect on the formation of Consumer Brand Engagement. They feel more confident when using these items in society. There was something of a certain strength and pride that emerged when they used this item. Consumers can express personal values on social media owned by the company in the form of "likes" or comments on discussion forums or uploaded products. They are also proud to be part of the brand. So that it will increase brand involvement as reflected in the positive attitude that consumers have towards the luxury goods they have. Previous research has also confirmed that the self expressiveness of luxury brands has an impact on CBE (Prentice and Loureiro, 2018) and has been tested in the context of application in social media (Oliveira and Fernandes, 2020).

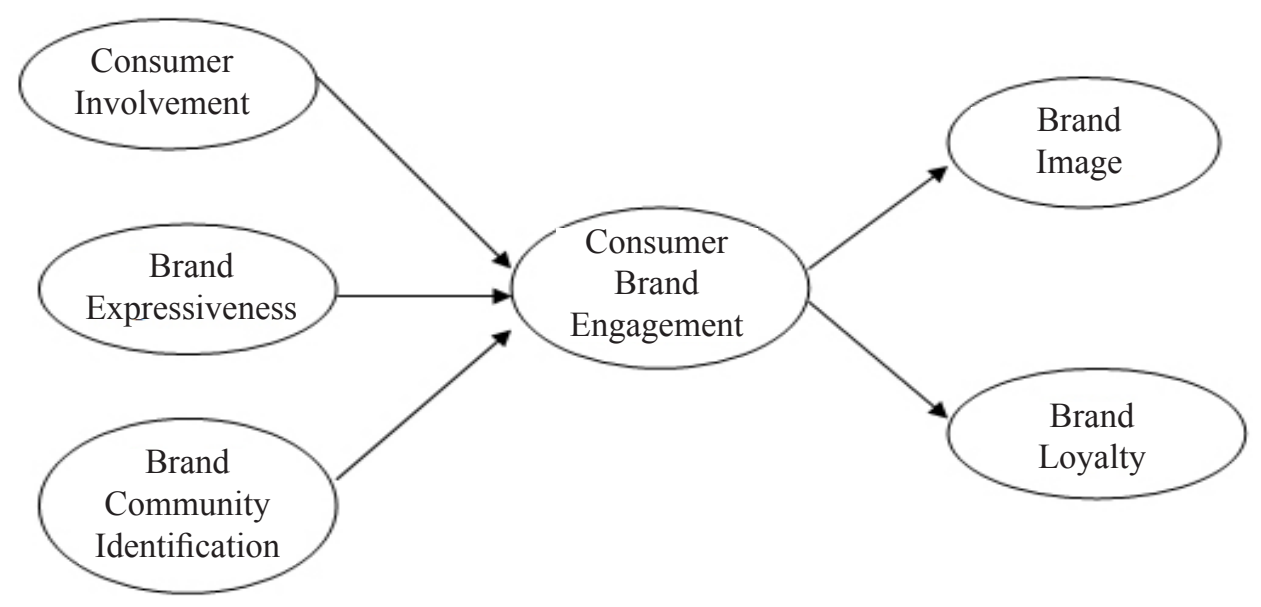

Figure 1. Research model 
Table 3. Bootstrapping test of path coefficient (total effect)

\begin{tabular}{|c|c|c|c|c|c|}
\hline & $\begin{array}{l}\text { Original } \\
\text { Sample }(O)\end{array}$ & $\begin{array}{l}\text { Sample } \\
\text { Mean (M) }\end{array}$ & $\begin{array}{c}\text { Standard } \\
\text { Deviation } \\
\text { (STDEV) }\end{array}$ & $\begin{array}{l}\text { T Statistics } \\
(|\mathrm{O} / \mathrm{STDEV}|)\end{array}$ & P Values \\
\hline $\begin{array}{l}\text { Consumer Involvement } \rightarrow \text { Consumer Brand } \\
\text { Engagement }\end{array}$ & 0.162 & 0.162 & 0.086 & 1.885 & 0.060 \\
\hline $\begin{array}{l}\text { Brand Self Expressiveness } \rightarrow \text { Consumer Brand } \\
\text { Engagement }\end{array}$ & 0.221 & 0.217 & 0.085 & 2.600 & 0.010 \\
\hline $\begin{array}{l}\text { Brand Community Identification } \rightarrow \text { Consumer } \\
\text { Brand Engagement }\end{array}$ & 0.538 & 0.541 & 0.088 & 6.124 & 0.000 \\
\hline Consumer Brand Engagement $\rightarrow$ Brand Image & 0.506 & 0.513 & 0.064 & 7.888 & 0.000 \\
\hline Consumer Brand Engagement $\rightarrow$ Brand Loyalty & 0.736 & 0.735 & 0.052 & 14.043 & 0.000 \\
\hline
\end{tabular}

The novelty of this research is to examine the role of brand community identification in forming $\mathrm{CBE}$ in luxury brands. Hypothesis 3 (H3) has a p-value of 0.000 which shows a positive and significant result. Brand community identification has a significant effect on the formation of consumer brand engagement. The results state that there is a significant effect on the formation of CBE. This model is following previous research of Kaur et al. (2019). The importance of brand community identification for luxury brand users on social media is because consumers feel part of the community that exists in luxury brands. After all, they have the same goal (Phua et al. 2016). So that marketers can use it to increase engagement in the marketing department carried out through social media. The higher the consumer feels part of the brand, the higher the desire to be involved in the brand.

After knowing the antecedents of CBE, marketers need to know about the positive impact that occurs when CBE increases in luxury brands. Adopting (Oliveira and Fernandes, 2020) in measuring CBE, researchers looked at cognitive, affective, and behavioural perspectives. The results found that the higher the CBE will encourage the creation of brand image and brand loyalty. Hypothesis 4 (H4) has a p-value of 0,000 which indicates a significant result. consumer brand engagement has a positive and significant effect on brand image. These results are in line with previous research (Cheung et al. 2020) which suggests the use of interesting content which is the reason CBE will stimulate consumer knowledge of brands to be positive. A good brand is characterized by good product quality. Consumers will prefer products that are felt to have more value than other products. This research can be seen from the involvement of consumers on social media.
The impact of $\mathrm{CBE}$ also increases brand loyalty. Hypothesis 5 (H5) has a p-value of 0.000 which shows significant results. Consumer brand engagement has a positive and significant effect on brand loyalty. The higher the customer involvement in social media, the higher the customer loyalty to the luxury brand. Customers will voluntarily provide recommendations to others and have a positive attitude that benefits the company when they feel involved in marketers activities on social media. This means that customers who are more involved in brand relationships, tend to be more loyal, which is beneficial for the company (Kaur et al. 2019).

\section{Managerial Implications}

This study also offers insights for marketing practitioners. First, managers of luxury brand companies must increase consumer engagement by taking into account the reasons consumers want to be involved with the brand. Several factors cause this involvement so that it can be used as input for marketers in developing marketing strategies such as brand community identification and brand self expressiveness. Testing on the indicator of brand involvement was also performed but the results were not significant. This is because consumer involvement in luxury brands is not marked by an exaggerated perception of the products they buy. So to increase customer engagement in brands, marketers must create a business culture based on a specific aura that is strongly associated with a rich heritage, dreams, myths, and legends, which is more than any other industry because the luxury market is linked to art shaping human values and dreams (König et al. 2018). Research also shows that marketers seek to influence consumers' emotional responses to brands by managing their social media activities effectively (Seo and Park, 2018). 
Marketers can also increase customer engagement by engaging social ties with other customers on social media or creating groups for users of the brand. So that consumers will feel they have something in common with other people and when there are obstacles or the latest information they want to know about certain luxury items, they can share information with others. The existence of an online community will make consumers feel safe in interacting (Hollebeek et al. 2017). Users will perceive luxury brands as a part of themselves and being active on social media as part of self-expression to others. They will engage, promote, and maintain product excellence as part of their admiration for the luxury brand.

We also found that when luxury brand companies can increase consumer engagement on social media, it will increase brand image and brand loyalty that will benefit the company. The increase in brand image is seen from consumer perceptions of the quality of the product which can only be seen through displays on social media. Therefore, social media can be used as a cost-effective tool to build a brand image (Godey et al. 2016). In the current digital era, it allows other people to freely access social media, there may also be other people who have not been able to buy it but have shown loyalty to the brands they participate in, such as providing advocacy. This unique thing can also be used as a form of involvement that must be managed properly. (Brodie et al. 2013) also explained that high brand loyalty can be obtained when someone is actively involved in the online community. So that the luxury brand manager must manage the community well. You can make a fan page on Facebook or create a YouTube channel with interesting content.

\section{CONCLUSIONS AND RECOMMENDATIONS}

\section{Conclusions}

Consumer brand engagement is an important discussion in the scope of social media today (Kaur et al. 2019; Algharabat et al. 2020; Cheung et al. 2020; Oliveira and Fernandes, 2020). However, due to the limitations of previous research that continues to build the antecedent variable of CBE, this study proposes a brand community identification variable as an effect of increasing social media CBE in luxury brands. The results of the study explained that brand community identification increases $\mathrm{CBE}$ in social media. These results are the latest discoveries in $\mathrm{CBE}$ on social media in the context of luxury brands. Marketers are advised to manage online communities on social media to increase customer engagement and ultimately increase brand image and brand loyalty.

\section{Recommendations}

This study has several limitations that can provide new directions for future research. This researcher only looks at the relationship between the CBE forming constructs on social media only up to a brand image and brand loyalty, not up to purchase intention. Dabbous and Barakat (2020) showed that when customers have high engagement with luxury brands on social media, it can increase purchase intention. So for further research, we can examine the relationship to purchase intention by using the consumer-brand identification variable. Further exploration can be carried out to find out other factors causing brand image and brand loyalty besides CBE so that it is more specific in seeing the form of customer involvement. The scope of this research is also limited to only focusing on luxury brands with limited respondent characteristics, so in the future, we can consider other product categories, especially service products.

\section{REFERENCES}

Algesheimer R, Dholakia UM, Herrmann A. 2005. The social influence of brand community: Evidence from European car clubs. Journal of Marketing 69(3):19-34.http://dx.doi.org/10.1509/ jmkg.69.3.19.66363.

Algharabat Retal. 2020. Investigating the antecedents of customer brand engagement and consumer-based brand equity in social media. Journal of Retailing and Consumer Services 53(Jan):101767. http:// dx.doi.org/10.1016/j.jretconser.2019.01.016.

Alvarez C, Fournier S. 2016. Consumers' relationships with brands. Current Opinion in Psychology 10:129-135. http://dx.doi.org/10.1016/j. copsyc.2015.12.017.

Appel $\mathrm{G}$ et al. 2020. The future of social media in marketing. Journal of the Academy of Marketing Science 48(1):79-95. http://dx.doi.org/10.1007/ s11747-019-00695-1. 
Aral S, Dellarocas C, Godes D. 2013. Social media and business transformation: A framework for research. Information Systems Research 24(1):313. http://dx.doi.org/10.1287/isre.1120.0470.

Athwal N, Istanbulluoglu D, McCormack SE. 2018. The allure of luxury brands' social media activities: A uses and gratifications perspective. Information Technology and People 32(3):603-626. http:// dx.doi.org/10.1108/ITP-01-2018-0017.

Atwal G, Williams A. 2017. Advances in luxury brand management. Advances in Luxury Brand Management 43-57. http://dx.doi. org/10.1007/978-3-319-51127-6.

Batat W.2019. How millennials and post-millennials are reshaping luxury. Management for Professionals 66-67. http://dx.doi.org/10.1007/978-3-03001671-5.

Bowden J. 2009. The process of customer engagement: A conceptual framework. Journal of Marketing Theory and Practice 17(1):63-74. http://dx.doi. org/10.2753/MTP1069-6679170105.

Brandão A, Pinho E, Rodrigues P. 2019. Antecedents and consequences of luxury brand engagement in social media. Spanish Journal of Marketing ESIC 23(2):163-183. http://dx.doi.org/10.1108/ SJME-11-2018-0052.

Britten B. 2013. Losing control: Using Social media to engage and connect. Journal of Magazine \& New Media Research 14(2):1-3.

Brodie RJ et al. 2011. Customer engagement: Conceptual domain, fundamental propositions, and implications for research. Journal of Service Research 14(3):252-271. http://dx.doi. org/10.1177/1094670511411703.

Brodie RJ et al. (2013) 'Consumer engagement in a virtual brandcommunity:Anexploratory analysis. Journal of Business Research 66(1):105-114. http://dx.doi.org/10.1016/j.jbusres.2011.07.029.

Bu Y, Parkinson J, Thaichon P. 2020. Digital content marketing as a catalyst for e-WOM in food tourism. Australasian Marketing Journal 9(2):142-154. http://dx.doi.org/10.1016/j. ausmj.2020.01.001

Chahal H, Rani A. 2017. How trust moderates social media engagement and brand equity Hardeep. Journal of Research in Interactive Marketing 34(3):312-335.

Chandon JL, Laurent G, Valette-Florence P. 2016. Pursuing the concept of luxury: Introduction to the JBR special issue on "luxury marketing from tradition to innovation". Journal of
Business Research 69(1):99-303. http://dx.doi. org/10.1016/j.jbusres.2015.08.001.

Chaudhuri A, Holbrook MB. 2001. The chain of effects from brand trust and brand affect to brand performance: The role of brand loyalty. Journal of Marketing 65(2):81-93. http://dx.doi. org/10.1509/jmkg.65.2.81.18255.

Chen H, Wang Y. 2017. Connecting or disconnecting: Luxury branding on social media and affluent Chinese female consumers' interpretations. Journal of Brand Management Palgrave Macmillan 24(6):562-574. http://dx.doi. org/10.1057/s41262-017-0050-8.

Chen SC, Lin CP. 2019. Understanding the effect of social media marketing activities: The mediation of social identification, perceived value, and satisfaction.TechnologicalForecastingandSocial Change Elsevier 140(Nov 2018):22-32. http:// dx.doi.org/10.1016/j.techfore.2018.11.025.

Cheung ML, Pires G, Rosenberger PJ. 2020. The influence of perceived social media marketing elements on consumer-brand engagement and brand knowledge. Asia Pacific Journal of Marketing and Logistics 32(3):695-720. http:// dx.doi.org/10.1108/APJML-04-2019-0262.

Chu SC, Kamal S, Kim Y. 2019. Re-examining of consumers' responses toward social media advertising and purchase intention toward luxury products from 2013 to 2018: A retrospective commentary. Journal of Global Fashion Marketing Routledge 10(1):81-92. http://dx.doi. org/10.1080/20932685.2018.1550008.

Coelho PS, Rita P, Santos ZR. 2018. On the relationship between consumer-brand identification, brand community, and brand loyalty. Journal of Retailing and Consumer Services 43(March):101-110. http://dx.doi.org/10.1016/j. jretconser.2018.03.011.

Cole MS, Bruch H. 2006. Organizational identity strength, identification, and commitment and their relationships to turnover intention: Does organizational hierarchy matter?. Journal of Organizational Behaviour 27:585-605. http:// dx.doi.org/10.1002/9781118786352.wbieg0200.

Dabbous A, Barakat KA. 2020. Bridging the online offline gap: Assessing the impact of brands' social network content quality on brand awareness and purchase intention. Journal of Retailing and Consumer Services 53(Nov 2018):101966. http:// dx.doi.org/10.1016/j.jretconser.2019.101966.

Dauriz L, Remy N, Sandri N. 2013. Luxury shopping 
in the digital age. Persepectives on retail and consumer goods 26-31.

Dwivedi A. 2015. A higher-order model of consumer brand engagement and its impact on loyalty intentions. Journal of Retailing and Consumer Services 24(C): 100-109. http://dx.doi. org/10.1016/j.jretconser.2015.02.007.

Fazli-Salehi R et al. 2020. Antecedents and outcomes of brand identification with Apple products among Iranian consumers. Journal of Relationship Marketing Routledge 0(0):1-21. http://dx.doi.or $\mathrm{g} / 10.1080 / 15332667.2020 .1755948$.

Febrian A et al. 2021. Digital content marketing strategy in increasing customer engagement in Covid-19 situation. International Journal of Pharmaceutical Research 13(01):4797-4805. http://dx.doi.org/10.31838/ijpr/2021.13.01.684.

Febrian A, Fadly M. 2021. The impact of customer satisfaction with implications for EWOM and brand equity on e-commerce purchase intention in Indonesia. Binus Business Review 12(1). http://dx.doi.org/10.21512/bbr.v12i1.6419.

Fernandes T, Moreira M. 2019. Consumer brand engagement, satisfaction and brand loyalty: A comparative study between functional and emotional brand relationships. Journal of Product and Brand Management 28(2):274-286. http:// dx.doi.org/10.1108/JPBM-08-2017-1545.

Fink $\mathrm{M}$ et al. 2018. Effective entrepreneurial marketing on Facebook - A longitudinal study. Journal of Business Research. http://dx.doi.org/10.1016/j. jbusres.2018.10.005.

Firmiyanti RD, Satria A, Saptono IT. 2019. Developing business strategy for local television network into the digital broadcasting competition in Indonesia: A JPM case study. Indonesian Journal of Business and Entrepreneurship 5(2):168-180. http://dx.doi.org/10.17358/ijbe.5.2.168.

Fornell C, Larcker DF. 1981. Evaluating structural equation models with unobservable variables and measurement error. Journal of Marketing Research 18(1):39. http://dx.doi. org/10.2307/3151312.

Foroudi $\mathrm{P}$ et al. 2018. Enhancing university brand image and reputation through customer value cocreation behaviour. Technological Forecasting and Social Change 138(July):218-227. http:// dx.doi.org/10.1016/j.techfore.2018.09.006.

Giakoumaki C, Krepapa A. 2020. Brand engagement in self-concept and consumer engagement in social media: The role of the source. Psychology and Marketing 37(3):457-465. http://dx.doi. org/10.1002/mar.21312.

Godey B et al. 2016. Social media marketing efforts of luxury brands: Influence on brand equity and consumer behavior. Journal of Business Research 69(12):5833-5841. http://dx.doi.org/10.1016/j. jbusres.2016.04.181.

Gómez M, Lopez C, Molina A. 2019. An integrated model of social media brand engagement. Computers in Human Behavior 96(Jan):196-206. http://dx.doi.org/10.1016/j.chb.2019.01.026.

Hagtvedt H, Patrick VM. 2009. The broad embrace of luxury: Hedonic potential as a driver of brand extendibility. Journal of Consumer Psychology: Society for Consumer Psychology 19(4):608-618. http://dx.doi.org/10.1016/j.jcps.2009.05.007.

Hair JF et al. 2014. Partial least squares structural equation modeling (PLS-SEM): An emerging tool in business research. European Business Review 26(2):106-121. http://dx.doi.org/10.1108/EBR10-2013-0128.

Harrigan P et al. 2017. Customer engagement with tourism social media brands. Tourism Management 59:597-609. http://dx.doi. org/10.1016/j.tourman.2016.09.015.

Helme-Guizon A, Magnoni F. 2019. Consumer brand engagement and its social side on brand-hosted social media: how do they contribute to brand loyalty?. Journal of Marketing Management Routledge 35(7-8):716-741. http://dx.doi.org/1 0.1080/0267257X.2019.1599990.

Hollebeek LD. 2011. Demystifying customer brand engagement: Exploring the loyalty nexus. Journal of Marketing Management 27(78):785-807. http://dx.doi.org/10.1080/0267257 X.2010.500132.

Hollebeek LD, Glynn MS, Brodie RJ. 2014. Consumer brand engagement in social media: Conceptualization, scale development and validation. Journal of Interactive Marketing 28(2):149-165. http://dx.doi.org/10.1016/j. intmar.2013.12.002.

Hollebeek LD, Juric B, Tang W. 2017. Virtual brand community engagement practices: A refined typology and model. Journal of Services Marketing 31(3):204-217. http://dx.doi. org/10.1108/JSM-01-2016-0006.

Islam JU, Rahman Z, Hollebeek LD. 2017. Internet Research consumer engagement in online brand communities: A solicitation of congruity theory Article information. Internet Research. http:// 
dx.doi.org/10.1108/IntR-09-2016-0279.

John H. 1999. Use of partial least squares (PLS) in Strategic management research: A review of four recent studies. Strategic Management Journal 20(4):195-204. http://dx.doi.org/10.1038/ aps.2012.31.

Kaur $\mathrm{H}$ et al. 2019. The role of brand community identification and reward on consumer brand engagement and brand loyalty in virtual brand communities. Telematics and Informatics 46:101321. http://dx.doi.org/10.1016/j. tele.2019.101321.

Kelly L, Kerr G, Drennan J. 2010. Avoidance of advertising in social networking sites. Journal of Interactive Advertising 10(2):16-27. http:// dx.doi.org/10.1080/15252019.2010.10722167.

Kim AJ, Ko E. 2010. Impacts of luxury fashion brand's social media marketing on customer relationship and purchase intention. Journal of Global Fashion Marketing 1(3):164-171. http://dx.doi. org/10.1080/20932685.2010.10593068.

Kim CK, Park S. 2001. The effect of brand personality and brand identification on brand loyalty: Applying the theory of social identification. Japanese Psychological Research 43(4):195206.

König JCL et al. 2018. ...And they lived luxury ever after: storytelling as a driver for luxury brand perception and consumer behaviour. Luxury Research Journal 1(4):283. http://dx.doi. org/10.1504/lrj.2018.10011920.

Laurent G, Kapferer JN. 1985. Measuring consumer involvement profiles. Journal of Marketing Research 22(1):41. http://dx.doi. org/10.2307/3151549.

Leckie C, Nyadzayo MW, Johnson LW. 2016. Antecedents of consumer brand engagement and brand loyalty. Journal of Marketing Management Routledge 32(5-6):558-578. http://dx.doi.org/1 0.1080/0267257X.2015.1131735.

Lina LF, Permatasari B. 2020. Social media capabilities dalam adopsi media sosial guna meningkatkan kinerja UMKM. Jembatan: Jurnal Ilmiah Manajemen 17(2):227-238. http://dx.doi. org/10.29259/jmbt.v17i2.12455.

Liu X, Shin H, Burns AC. 2019. Examining the impact of luxury brand's social media marketing on customer engagement: Using big data analytics and natural language processing. Journal of Business Research 125:815-826. http://dx.doi. org/10.1016/j.jbusres.2019.04.042.
Machado JC et al. 2019. Brand gender and consumerbased brand equity on Facebook: The mediating role of consumer-brand engagement and brandlove. Journal of Business Research 96(Jun):376-385. http://dx.doi.org/10.1016/j.jbusres.2018.07.016.

Martín-Consuegra D et al. 2019. Examining consumer luxury brand-related behavior intentions in a social media context: The moderating role of hedonic and utilitarian motivations', Physiology and Behavior 200:104-110. http://dx.doi. org/10.1016/j.physbeh.2018.03.028.

Matzler K et al. 2011. Personality, person-brand fit, and brand community: An investigation of individuals, brands, and brand communities. Journal of Marketing Management 27(9-10):874-890. http://dx.doi.org/10.1080/0267257X.2010.54363 4.

Nielsen Research (2019) How U.S millennials are shaping online FMCG shopping trends. https:// www.nielsen.com/us/en/insights/article/2019/ how-us-millennials-are-shaping-online-fmcgshopping-trends/. [1 July 2020].

Oh J, Bellur S, Sundar SS. 2015. Clicking, assessing, immersing, and sharing: An empirical model of user engagement with interactive media. Communication Research 45(5):737-763. http:// dx.doi.org/10.1177/0093650215600493.

Oliveira M, Fernandes T. 2020. Luxury brands and social media: drivers and outcomes of consumer engagement on Instagram. Journal of Strategic Marketing Routledge:1-19. http://dx.doi.org/10.1 080/0965254x.2020.1777459.

Oliver RL. 1999. Whence consumer loyalty. American Marketing Assocoiation 33-44.

Park M, Im H, Kim HY. 2018. You are too friendly!. The negative effects of social media marketing on value perceptions of luxury fashion brand. Journal of Business Research 1-17. http://dx.doi. org/10.1016/j.jbusres.2018.07.026.

Phan M, Thomas R, Heine K. 2011. Social media and luxury brand management: The case of burberry. Journal of Global Fashion Marketing 2(4):213222. http://dx.doi.org/10.1080/20932685.2011.10 593099.

Phua J, Jin SV, Kim J. 2016. Gratifications of using Facebook, Twitter, Instagram, or Snapchat to follow brands: The moderating effect of social comparison, trust, tie strength, and network homophily on brand identification, brand engagement, brand commitment, and membership intentio. Telematics and Informatics 
34(1):412-424. http://dx.doi.org/10.1016/j. tele.2016.06.004.

Prentice C, Loureiro SMC. 2018. Consumer-based approach to customer engagement - The case of luxury brands. Journal of Retailing and Consumer Services 43(April):325-332. http:// dx.doi.org/10.1016/j.jretconser.2018.05.003.

Qiao L, Song M, Wang N. 2019. Virtual brand community experience, identification, and electronic word-of-mouth. Journal of Computer Information Systems 1-14. http://dx.doi.org/10.1 080/08874417.2019.1661805.

Rigdon EE. 2016. Choosing PLS path modeling as analytical method in European management research: A realist perspective. European Management Journal 34(6):598-605. http:// dx.doi.org/10.1016/j.emj.2016.05.006.

Del Río AB, Vázquez R, Iglesias V. 2001. The effects of brand associations on consumer response. Journal of Consumer Marketing 18(5):410-425. http://dx.doi.org/10.1108/07363760110398808.

Rozzenkrants B, Wheeler SC, Shiv B. 2017. Selfexpression cues in product rating distributions. Journal of Consumer Research 44(4):1-66.

Sarstedt M et al. 2016. Estimation issues with PLS and CBSEM: Where the bias lies!.Journal of Business Research The Authors 69(10):3998-4010. http:// dx.doi.org/10.1016/j.jbusres.2016.06.007.

Scheinbaum AC. 2016. Digital engagement: Opportunities and risks for sponsors: Consumerviewpoint and practical considerations for marketing via mobile and digital platforms. Journal of Advertising Research 56(4):341-345. http://dx.doi.org/10.2501/JAR-2016-040.

Schultz DE. 2007. Focus on brand changes rules of engagement. Marketing News 15(8):7-8.

Seo EJ, Park JW. 2018. A study on the effects of social media marketing activities on brand equity and customer response in the airline industry. Journal of Air Transport Management 66(Sept): 36-41. http://dx.doi.org/10.1016/j. jairtraman.2017.09.014.
Shanahan T, Tran TP, Taylor EC. 2019. Getting to know you: Social media personalization as a means of enhancing brand loyalty and perceived quality. Journal of Retailing and Consumer Services 47(Jan):57-65. http://dx.doi.org/10.1016/j. jretconser.2018.10.007.

Stokburger-Sauer N, Ratneshwar S, Sen S. 2012. Drivers of consumer-brand identification. International Journal of Research in Marketing 29(4):406-418. http://dx.doi.org/10.1016/j. ijresmar.2012.06.001.

Tajfel H. 1982. Social psychology of intergroup relations. Annual Review of Psychology (33):139.

Teo LX, Leng HK, Phua YXP. 2018. Marketing on Instagram: Social influence and image quality on perception of quality and purchase intention. International Journal of Sports Marketing and Sponsorship 20(2):321-332. http://dx.doi. org/10.1108/IJSMS-04-2018-0028.

Teresa $\mathrm{M}$ et al. 2014. Digital marketing and social media :Whybother ?.http://dx.doi.org/10.1016/j. bushor.2014.07.002.

Vigneron F, Johnson LW. 2004. Measuring perceptions of brand luxury. Brand Management 11(6):484 506.

de Villiers R. 2015. Consumer brand enmeshment: Typography and complexity modeling of consumer brand engagement and brand loyalty enactments. Journal of Business Research 68(9):1953-1963. http://dx.doi.org/10.1016/j. jbusres.2015.01.005.

Vivek SD, Beatty SE, Morgan RM. 2012. Customer engagement: Exploring customer relationships beyond purchase. Journal of Marketing Theory and Practice 20(2):122-146. http://dx.doi. org/10.2753/MTP1069-6679200201.

Zaichkowsky JL. 1985. Measuring the Involvement Construct. Journal of Consumer Research 12. http://dx.doi.org/10.1300/j047v06n04_05. 